\title{
Contamination of Environment with the Heavy Metals Emitted from a Cement Factory, Kosovo
}

\author{
Skender Demaku', Kaltrina Jusufi' ${ }^{*}$, Gani Kastrati ${ }^{2}$ \\ 1 Department of Chemistry, Faculty of Natural Sciences, University of Prishtina. Mother Thereza, Street, 5, \\ 10000 Pristina, Republic of Kosovo \\ 2 University for Business and Technology - Food Science and Biotechnology, Republic of Kosovo \\ * Corresponding author's e-mail: kaltrina.jusufi@uni-pr.edu
}

\begin{abstract}
The environment and its components have been severely contaminated over the years due to massive pollution. The multiple use of heavy metals in industrial, domestic, agricultural, medical and technological applications have led to their wide distribution in the environment. Different studies implied that the primary contribution to the ecological risk index, originated from various anthropogenic influences such as industrialization and urbanization. This has compromised the ability of the environment to foster life and render its intrinsic values due to the heavy usage of these elements. This research illustrates the assessment of heavy metals in waste, water, sludge and soil. Monitoring was performed in vicinity of a cement factory on the southern Kosovo, where the sampling and measurements were performed in the autumn season of 2018. With the use of atomic absorption spectroscopy technique (AAS), the elements determined in this study were $\mathrm{Pb}$, $\mathrm{Zn}, \mathrm{Cu}, \mathrm{Ni}, \mathrm{Fe}, \mathrm{Mn}$, and $\mathrm{Al}$. The findings of this study revealed a little change in the concentrations of these elements in the environment samples, especially in water, apart from that there is slight pollution of the environment with heavy metals in this zone.
\end{abstract}

Keywords: Sharrcem, cement factory, heavy metals, water.

\section{INTRODUCTION}

The ancient sign of the existence of life in earth, is the presence of water. Even though the issue of water and its purity is problematic today, living without clean and sufficient water is impossible (Kilaru et al., 2019). Soil is considered an important natural resource of pollution, due of its capability to act as a geochemical reservoir for various contaminants, including heavy metals, resulting from the aerosol deposition through urban and manufacturing activities (Liu et al., 2014; Nagajyoti et al., 2010). Soil can also act as a natural buffer and therefore can control the dispersal of chemical contaminants in the air, water and biological components. (Lutts et al., 2015). Numerous studies have shown that soil contamination with heavy metals in soils also result in the contamination of food cultivated in those agricultural soils (Jusufi et al., 2017a; Prabhat et al., 2019; Jusufi et al., 2017b).

The anthropogenic activities such as construction, energy production, industrial mining, fossil fuel combustion and waste disposal, resulted in the uncharacteristic deposition of heavy metals in urban soil resulting in severe environmental pollution (Demaku et al., 2020; Demaku et al., 2019; Wekpel et al., 2019; Jusufi et al., 2016; Boateng et al., 2019). The industries involved in cement production are also an enormous source of environmental pollution due to the emission of dust that contains toxic chemicals, which vary according to the raw materials used (Isikli et al., 2003, Isikli et al., 2006).

Many of the heavy metals produced also as a byproduct of cement industrial activities are known to be toxic for living organisms, even in minimal concentrations. This study is based on 
the heavy metal contamination in the vicinity area of the "Sharrcem" cement factory in Kosovo. The results are presented in figures and statistical analysis.

\section{MATERIAL AND METHODS}

\section{Study Area}

Elez Han is a town and municipality located in the Ferizaj District of Kosovo. This region of the country is also known as an industrial zone due to the cement factory located in this area. Figure 1 shows the map of Kosovo with the study area (near the Sharrcem factory).

\section{Treatment of water sample}

In each sampling point, two samples of water were taken in 21 glass bottles. Initially, the water samples were filtered, before placing them into a Teflon vessels. The samples were then treated with $1 \mathrm{~mL}$ of $\mathrm{HCl}$ and $5 \mathrm{~mL}$ of $\mathrm{HNO}_{3}$ as well as digested in a BERGHOF-Speed Wave microwave (Canbay et al., 2016)

\section{Treatment of soil, waste and sludge samples}

The solid samples (soil, waste and sludge) were prepared according to the (Kadhum et al, 2015), weighting 3.5 gram of solid sample and placed them in Teflon vessels. The samples were then treated with $10 \mathrm{ml}$ of aqua regia and digested in a microwave. After the microwave digestion was finished, the samples were filtered, diluted to $100 \mathrm{ml}$ using distilled water (USEPA Method 3050B 1996)

\section{Instrumentation}

All chemicals needed for the determination of elements were of the "pro analysis" chemical purity. Atomic Absorption Spectroscopy (AAS) was used to measure the concentrations of heavy metals. For each group of analytical samples, two spiked blanks and two method blanks were simultaneously processed.

\section{RESULTS AND DISCUSSION}

In order to assess the concentration of heavy metals, four different components (water, sludge, waste and soil) were determined at three sampling points. The results are presented in $\mathrm{mg} / \mathrm{kg}$ content, respectively $\mathrm{mg} / \mathrm{l}$ for water.

\section{Waste results}

The risk that could come as a result of heavy metal discharging without prior treatment, can be enormous. Vongdala et al. (2018), reported that the waste dumping with high concentration

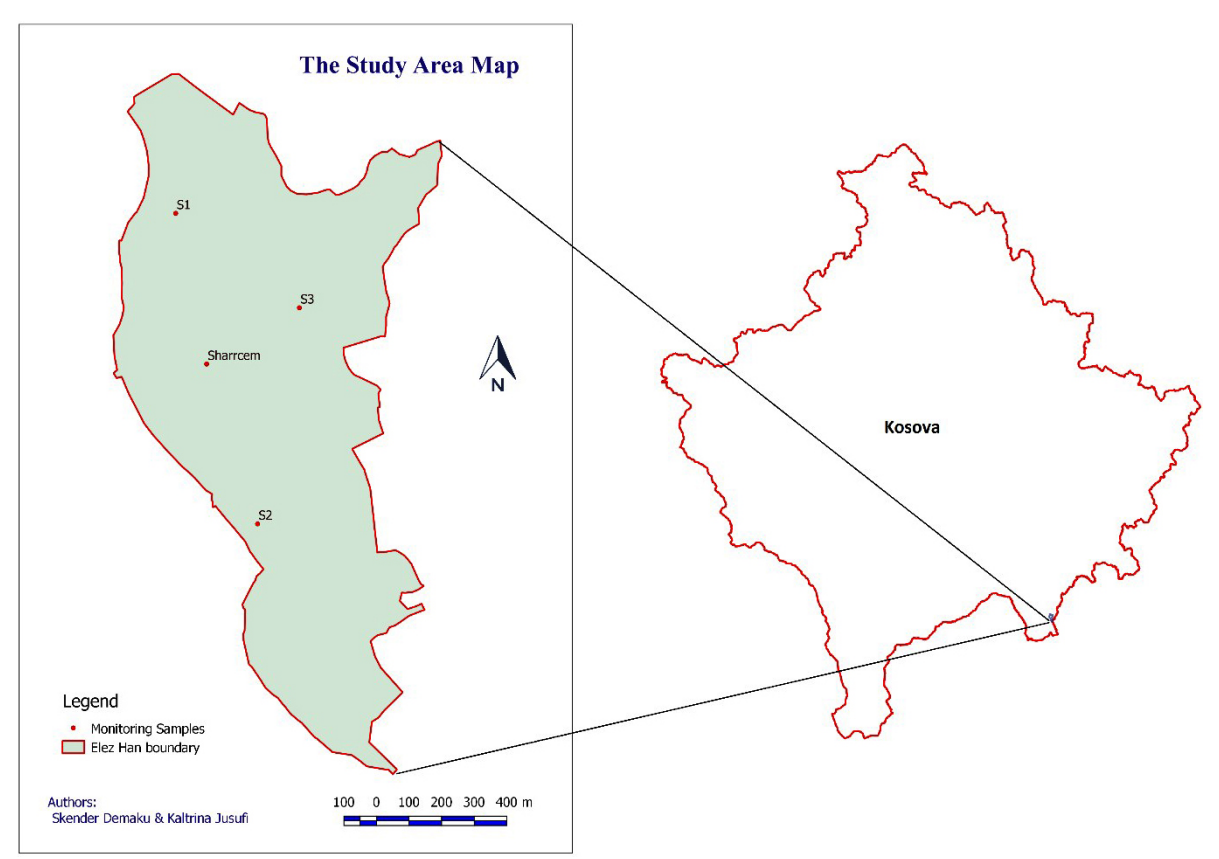

Figure 1. Map of Kosovo and the studied area near "Sharrcem" cement industry 
of these elements, resulted in an increase of this contamination in soil, water or even in plants that were grown in those areas. Figure 2 shows the graphical results of these elements in the waste samples given in $\mathrm{mg} / \mathrm{kg}$ of their mass.

If the results presented above are considered, as a remaining part of a solid substance, compared with the EU standard recommended (EU Directive 2018/852, 2018), it can be seen that the concentration of elements did not exceed the amount allowed. The higher concentration of the elements was observed in sampling point number 3 (S3), with the maximum Al concentration of $1.991 \mathrm{mg} / \mathrm{kg}, \mathrm{Fe}$ of $1.895 \mathrm{mg} / \mathrm{kg}, \mathrm{Mn}$ of $1.748 \mathrm{mg} / \mathrm{kg}$ and $\mathrm{Ni}$ of $1.095 \mathrm{mg} / \mathrm{kg}$. As far as the concentration of copper, zinc and lead is concerned, lower values were recorded in this monitoring zone. Figure 3 shows the distance distribution dendrogram of these elements $(\mathrm{Pb}$, $\mathrm{Zn}, \mathrm{Cu}, \mathrm{Ni}, \mathrm{Fe}, \mathrm{Al}$ and $\mathrm{Mn}$ ) in the analyzed samples of waste.

From the results obtained in Figure 3, it can be see that there is a high similarity of the elements in general. $\mathrm{Al}, \mathrm{Fe}$ and $\mathrm{Cu}$ are presented separately as elements. In all the cases, these elements showed high percentage of resemblance. In the case of $\mathrm{Al}$ for example, its similarity is about $77 \%$ with $\mathrm{Pb}$ and $\mathrm{Ni}$ group and in the right side of the diagram, Fe showed resemblance with the Mn and $\mathrm{Ni}$ groups with around $99 \%$ similarity. $\mathrm{Cu}$ in the right side of the dendrogram was presented separately from the other elements, with the resemblance to iron of $97 \%$.

If all the results presented in the figure 3 are compared, high percentage of similarity of element can be seen. From these results, it can be concluded that the source of contamination with these metals comes from the Cement Factory waste (Skoczylas and Rucińska, 2020, Tahri et al., 2005).

\section{Soil results}

Heavy metals are substances with the odd properties. Due to their ubiquity, toxicity at a trace level, bioaccumulation and persistence and so on, these elements have been attracting much attention worldwide Furthermore, heavy metals that have been accumulated in soils can infiltrate to other ecosystems: water, rivers, crops and so on. Figure 4 shows the graphical results of these elements in the soil samples given in $\mathrm{mg} / \mathrm{kg}$ of their mass.

The concentration of heavy metals in agricultural areas in three sampling points is different and it varies depending on the concentration of the element in an increasing order $\mathrm{Ni}<\mathrm{Fe}<\mathrm{Al}$. The highest concentration of nickel was observed in sample number 2 (S2) with $1.074 \mathrm{mg} / \mathrm{kg}$ and the lowest reached $0.151 \mathrm{mg} / \mathrm{kg}$. The concentration of iron varied in the range of $0.984-1.283 \mathrm{mg} / \mathrm{kg}$. Aluminium had the highest concentration in the $\mathrm{S} 21.432-0.993 \mathrm{mg} / \mathrm{kg}$. If the results are compared with the Dutch list for soil standards (Dutch target and Intervention Values. 2000), none of the elements exceeded the maximum amount allowed according to this list. Moreover, the concentration of other elements measured $(\mathrm{Cu}, \mathrm{Zn}, \mathrm{Pb}$ and $\mathrm{Mn})$ were below the maximum amount allowed compared to the Dutch list for soils. Figure 5 shows the

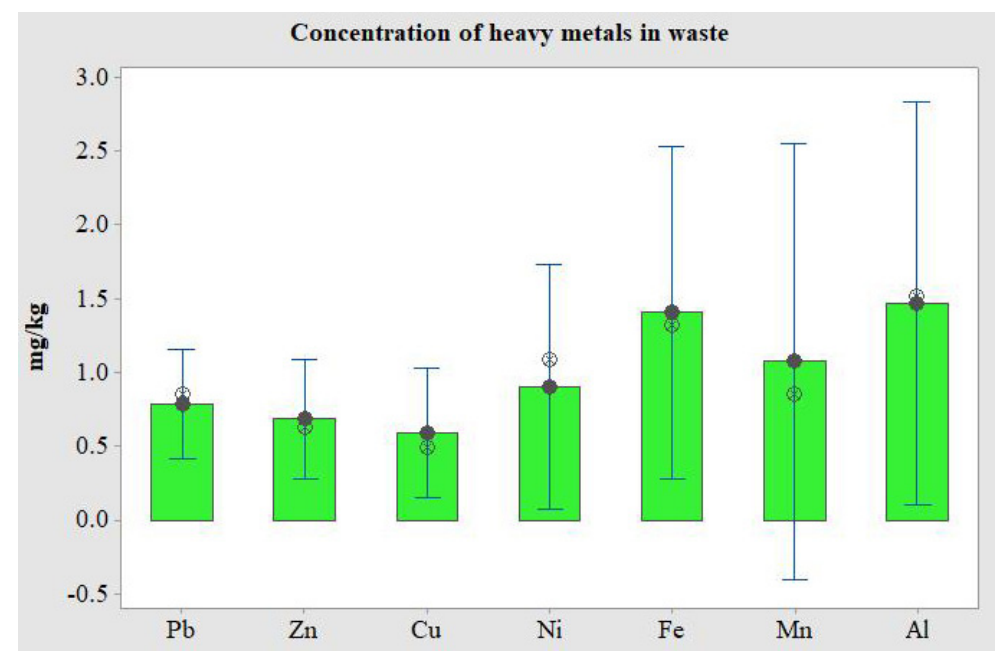

Figure 2. Concentration of heavy metals in waste, expressed in $\mathrm{mg} / \mathrm{kg}$. 


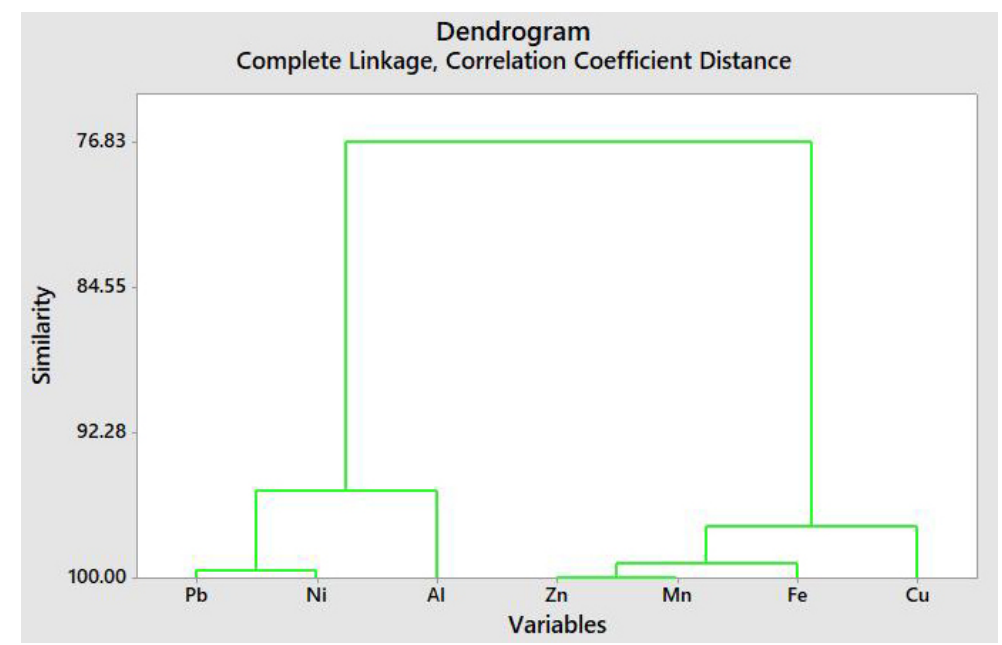

Figure 3. Distribution dendrogram of $\mathrm{Pb}, \mathrm{Zn}, \mathrm{Cu}, \mathrm{Ni}, \mathrm{Fe}, \mathrm{Al}$ and $\mathrm{Mn}$ in the analyzed samples of waste

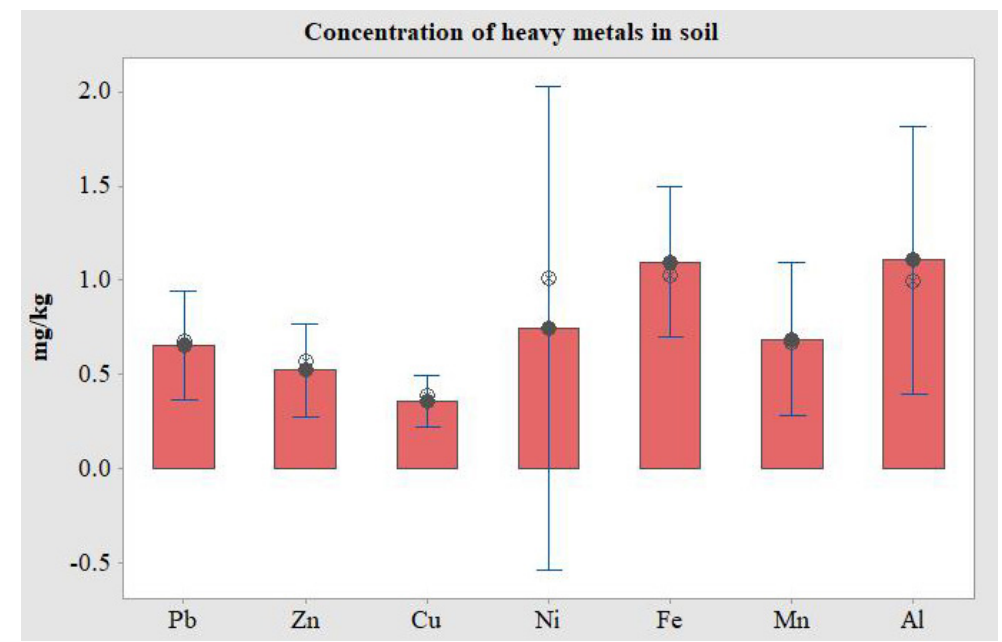

Figure 4. Concentration of heavy metals in soil, expressed in $\mathrm{mg} / \mathrm{kg}$

distance distribution dendrogram of these elements $(\mathrm{Pb}, \mathrm{Zn}, \mathrm{Cu}, \mathrm{Ni}, \mathrm{Fe}, \mathrm{Al}$ and $\mathrm{Mn})$ in the analyzed samples of soils.

In figure 5 presents the elements divided into three main groups of elements, according to their distribution similarity. The first group is between the $\mathrm{Pb}$ and $\mathrm{Mn}$ with almost $90 \%$ of similarity, group $2 \mathrm{Cu}$ and $\mathrm{Ni}$ close to $100 \%$ of resemblance and the third group is between $\mathrm{Fe}$ and Al with the percentage of $98 \%$. Zinc is presented alone with the similarity to the second group $(\mathrm{Cu}$ and $\mathrm{Ni}$ ) of about $95 \%$.

The case of the similarity of these elements distributed in the soils in the vicinity of cement factory, a very high similarity percentage of these elements in soils can be seen. Thus, it can be conclude that they came from the same source.

\section{Sludge results}

The high amount of sludge in the environment comes as a result of industrial overload. However, another concern that may arise from this high urbanization, is that the sludge has a high concentration of pollutants that are deposited in there. Figure 6 shows the graphical results of these elements in the sludge samples given in $\mathrm{mg} / \mathrm{kg}$ of their mass.

Wang et al. 2015 reported that the concentrations of heavy metals in sludge are higher especially after the atmospheric rain in the river and its shore. The highest concentration observed for lead is $0.898 \mathrm{mg} / \mathrm{kg}$, for nickel is $0.997 \mathrm{mg} / \mathrm{kg}$ and for $\mathrm{Al}-1.621 \mathrm{mg} / \mathrm{kg}$. In turn, the concentrations of copper, manganese and zinc are lower. If these results are compared, it can be see that in every case the concentration of these elements in 


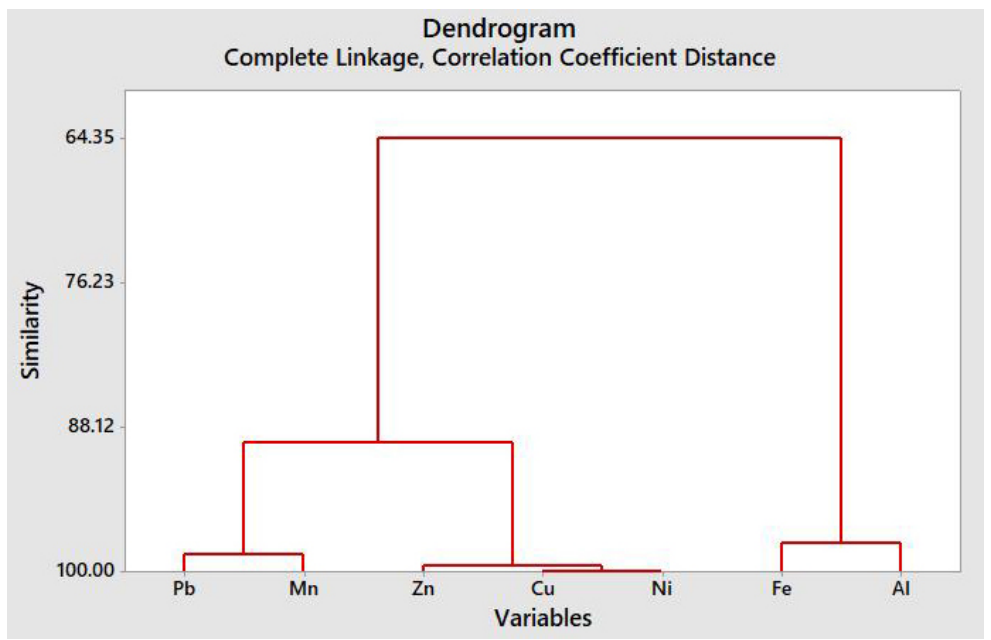

Figure 5. Distribution dendogram of $\mathrm{Pb}, \mathrm{Mn}, \mathrm{Zn}, \mathrm{Cu}, \mathrm{Ni}, \mathrm{Fe}$, and $\mathrm{Al}$ in analyzed soil samples

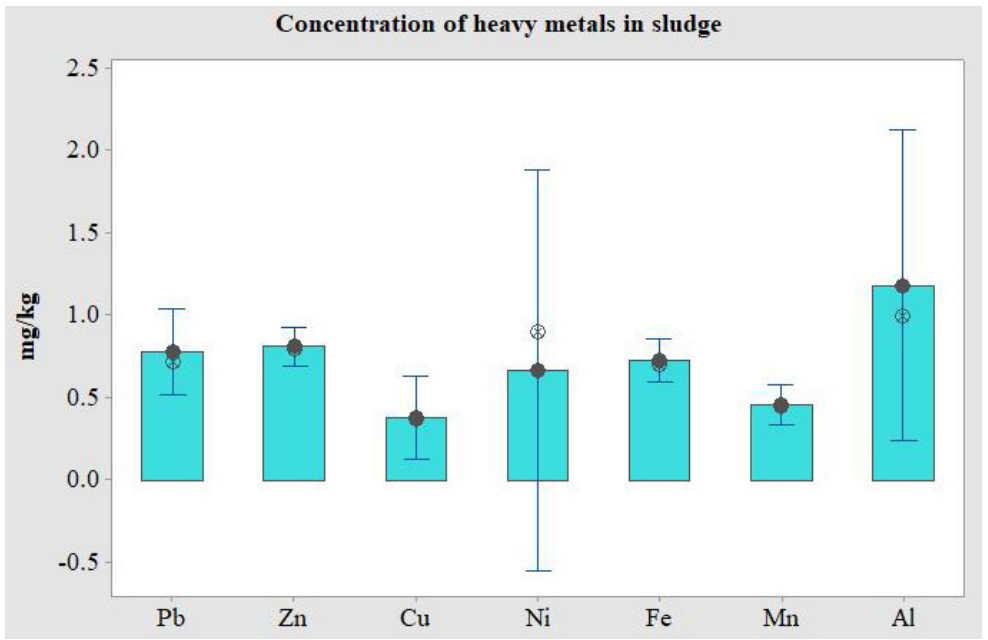

Figure 6. Concentration of heavy metals in sludge expressed in $\mathrm{mg} / \mathrm{kg}$.

sludge is lower than compared to the Dutch list for soils. (Dutch Target and Intervention Values, 2000). Figure 7 shows the distance distribution dendrogram of these elements $(\mathrm{Pb}, \mathrm{Zn}, \mathrm{Cu}, \mathrm{Ni}$, $\mathrm{Fe}, \mathrm{Al}$ and $\mathrm{Mn}$ ) in the analyzed samples of sludge.

Figure 7 shows the similarity of the elements based on their distribution in the sludge samples near the cement factory in Kosovo. According to the results presented in this figure, the highest similarity is presented between $\mathrm{Pb}, \mathrm{Al}$ and Fe with over $99 \%$, while in the another group of elements, $\mathrm{Cu}, \mathrm{Mn}$ and $\mathrm{Zn}$ have a percentage of about $99 \%$. Nickel in this diagram is presented as the only element with a high resemblance to both groups of compared elements.

\section{Water results}

Water pollution is one of the greatest concerns of the century. It is very easy from the atmospheric and soil pollution to infiltrate to water. From water, all kinds of free contaminants can end up in the food chain. Figure 7 shows the graphical results of these elements in the water samples given in $\mathrm{mg} / \mathrm{l}$.

The concentration of heavy metals that were determined in the river Lepenc are as followed: for $\mathrm{Ni}$ the highest concentration found is $0.098 \mathrm{mg} / \mathrm{l}$, Cu ranges from $0.163-0.189 \mathrm{mg} / \mathrm{l}$, $\mathrm{Zn}$ varies from 0.17 to $0.198 \mathrm{mg} / \mathrm{l}$ and the maximum amount for $\mathrm{Fe}$ is $0.588 \mathrm{mg} / \mathrm{l}$. The results presented for $\mathrm{Mn}$ and $\mathrm{Pb}$ are lower than the other elements. The concentration of lead varies from 0.06 to $0.099 \mathrm{mg} / \mathrm{l}$, while for manganese, the lowest concentration is $0.04-0.068 \mathrm{mg} / \mathrm{L}$. Aluminium was also found in lower concentrations, ranging from $0.654-0.878 \mathrm{mg} / \mathrm{l}$. If the results are compared according to the sampling points found, it can be see that the higher concentrations of these elements in water were found in 


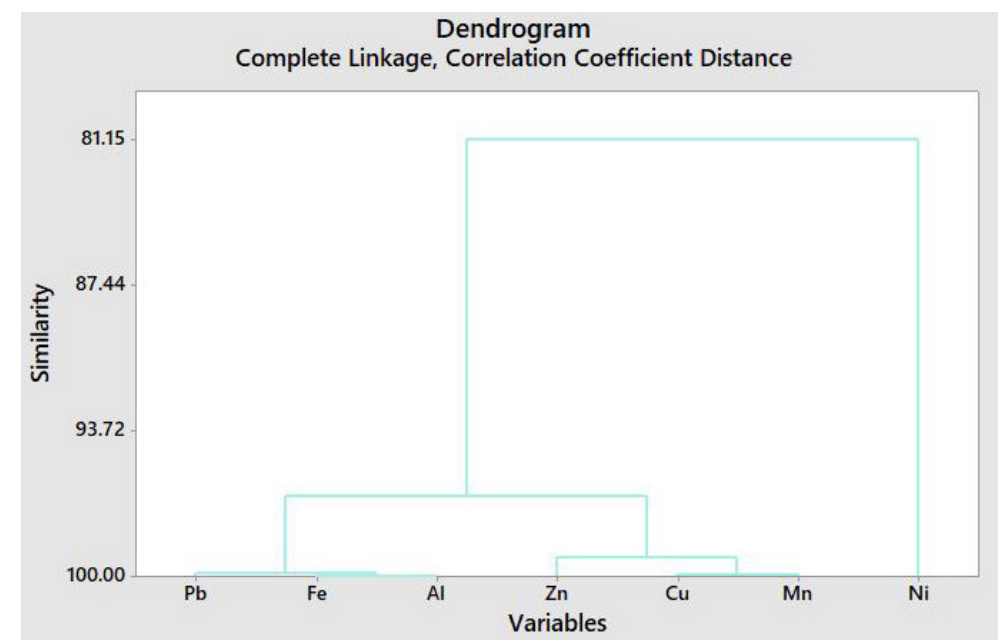

Figure 7. Distribution dendrogram of $\mathrm{Pb}, \mathrm{Mn}, \mathrm{Zn}, \mathrm{Cu}, \mathrm{Ni}, \mathrm{Fe}$, and $\mathrm{Al}$ in the analyzed sludge samples.

the second sampling point (S2). Figure 9 shows the distance distribution dendrogram of these elements $(\mathrm{Pb}, \mathrm{Zn}, \mathrm{Cu}, \mathrm{Ni}, \mathrm{Fe}, \mathrm{Al}$ and $\mathrm{Mn})$ in the analyzed samples of water.

The dendrogram presented above, represents the similarity percentage of lead, nickel, manganese, zinc, copper, iron and aluminum in the water samples. From the results obtained, it can be seen the high similarity between $\mathrm{Zn}, \mathrm{Ni}$ and $\mathrm{Mn}$ with almost $100 \%$. There is also high percentage of similarity of lead with this group of elements (more than 98\%). On the other side of dendogram, there is similarity of $\mathrm{Cu}$ and $\mathrm{Fe}$ reaching around $100 \%$. Aluminum is presented alone with high similarity to both these groups of elements (around 90\%). From the results obtained, it can be concluded that the source of these elements in water comes from the Cement Factory in this region.

\section{Statistical data}

The following analysis and tables show the statistical data of pollution and distribution of these elements in water, soil, sludge and waste samples. If the results are compared with the literature and standards, it can be see that in most of the cases the concentration of these elements is below the limits provided by these results.

Copper in drinking and pure water can be very low in concentrations (only a few $\mathrm{mg} / \mathrm{L}$ ), but plumbing can result in an increased concentration (WHO, 1993). The results of this element in this study in sludge samples is around $0.28-0.48 \mathrm{mg} / \mathrm{kg}$ and in every sample presented, the results are below the maximum amount allowed compared to the EU standards in sludge. Similarly, for soil samples, copper is lower than $36 \mathrm{mg} / \mathrm{kg}$ (according to the Dutch list) as a target value in soils.

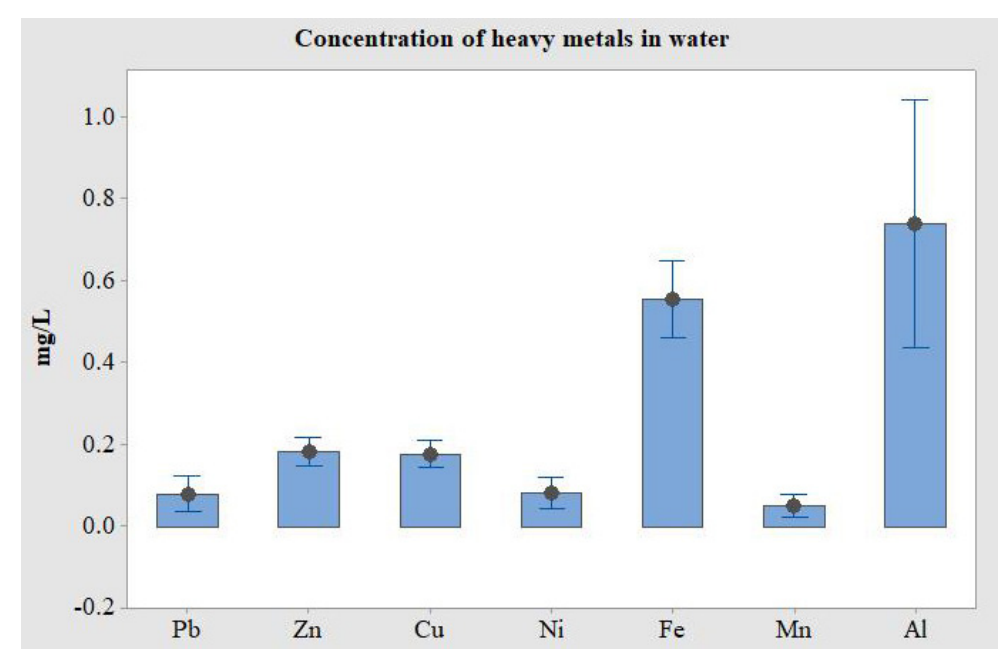

Figure 8. Concentration of heavy metals in water expressed in $\mathrm{mg} / \mathrm{l}$ 


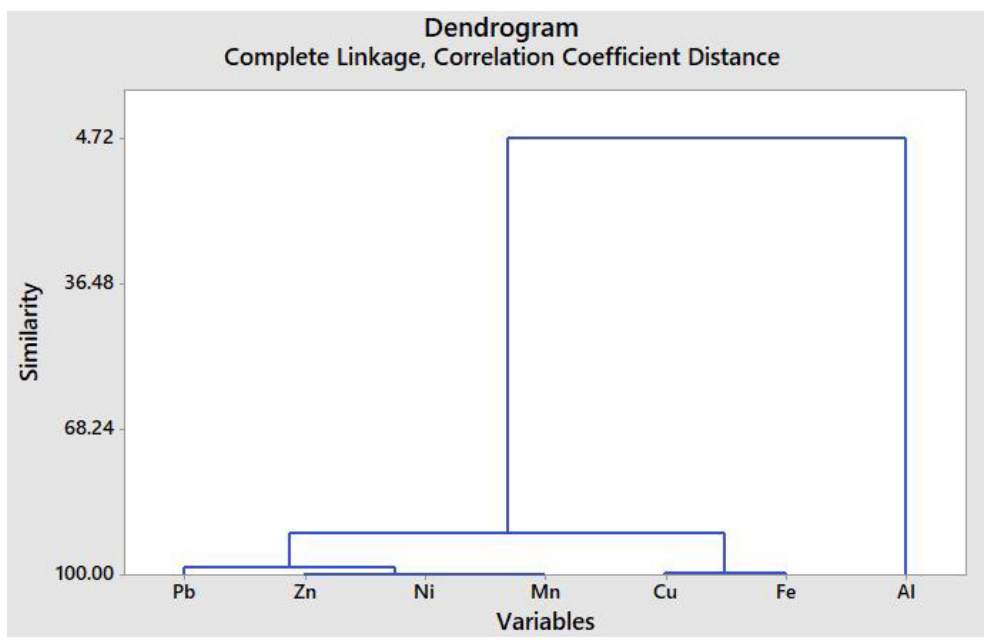

Figure 9. Distribution dendrogram of $\mathrm{Pb}, \mathrm{Mn}, \mathrm{Zn}, \mathrm{Cu}, \mathrm{Ni}, \mathrm{Fe}$, and $\mathrm{Al}$ in the analyzed water samples

Lead is widely used as a lead-acid batteries, allows etc. Most lead in drinking water can come from plumbing in buildings (WHO, 1993).

From the results observed from our measurements it can be seen that lead concentration is from $0.614-0.889 \mathrm{mg} / \mathrm{kg}$ in the waste samples. In soil, it varies from 0.531 to $0.758 \mathrm{mg} / \mathrm{kg}$, in the sludge samples $0.711-0.898 \mathrm{mg} / \mathrm{kg}$ and in the water samples, the lowest concentration reached the value of 0.071 , while the highest $-0.099 \mathrm{mg} / \mathrm{L}$. In all the measured samples, it can be see that there are lower concentrations than those recommended from relevant standards for maximum amount allowed values (Table 2) .In the case of soil samples, lead has a lower value than $85 \mathrm{mg} / \mathrm{kg}$ which is the target value according to this standard. When it comes to the results of lead in the water samples, it ranges from 0.071 to $0.099 \mathrm{mg} / \mathrm{L}$. Environmental Protection Agency (EPA) gives the maximum amount allowed for $\mathrm{Pb}$ around $15 \mu \mathrm{g} / \mathrm{L}$, so in most of the considered samples, it exceeded the maximum amount allowed than EPA recommends.
Zinc is an essential trace element found in a lot of foods and potable water in the form of salts or organic complexes. Although the levels of zinc in water normally do not exceed $0.01-0.05 \mathrm{mg} / \mathrm{l}$, the concentrations in tap water can be much higher as a result of dissolution of zinc from pipes. The concentration of $\mathrm{Zn}$ in the investigated soil samples is from $0.408-0.586 \mathrm{mg} / \mathrm{kg}$, while the value for soil standard (Dutch List) is around $140 \mathrm{mg} / \mathrm{kg}$, so this measured element in soil is under the maximum amount allowed. Moreover, in the water samples, this element is below the allowed limits as compared with the EPA standards which recommend that $\mathrm{Zn}$ should be less than $5 \mathrm{mg} / \mathrm{l}$.

Nickel showed lower value than the Dutch standards for soils $(36 \mathrm{mg} / \mathrm{kg})$. In the considered soil samples, the maximum concentration was $1.074 \mathrm{mg} / \mathrm{kg}$. In the water samples the concentration of this element is higher than compared with drinking water standard (Table 1). In the studied water samples, nickel is five times higher

Table 1. Ranging results of elements in the samples of waste, soil, water and sludge

\begin{tabular}{|c|c|c|c|c|c|c|c|}
\hline Elements & $\begin{array}{c}\text { Waste } \\
\mathrm{mg} / \mathrm{kg}\end{array}$ & $\begin{array}{c}\text { Soil } \\
\mathrm{mg} / \mathrm{kg}\end{array}$ & $\begin{array}{c}\text { Sludge } \\
\mathrm{mg} / \mathrm{kg}\end{array}$ & $\begin{array}{c}\text { Water } \\
\mathrm{mg} / \mathrm{l}\end{array}$ & $\begin{array}{c}\text { Soil } \\
\mathrm{mg} / \mathrm{kg}\end{array}$ & $\mathrm{mg} / \mathrm{kg}$ & Water $^{2}$ \\
\hline $\mathrm{Pb}$ & $0.614-0.889$ & $0.531-0.758$ & $0.711-0.898$ & $0.071-0.099$ & 85 & & $10 \mu \mathrm{g} / \mathrm{l}$ \\
\hline $\mathrm{Zn}$ & $0.559-0.87$ & $0.408-0.586$ & $0.772-0.865$ & $0.17-0.198$ & 140 & $>90^{*}$ & $5 \mathrm{mg} / /^{2}$ \\
\hline $\mathrm{Cu}$ & $0.485-0.798$ & $0.298-0.397$ & $0.286-0.486$ & $0.163-0.189$ & 36 & $>25^{*}$ & $2 \mathrm{mg} / \mathrm{l}$ \\
\hline $\mathrm{Ni}$ & $0.515-1.095$ & $0.151-1.074$ & $0.106-0.997$ & $0.079-0.098$ & 35 & $>20^{*}$ & $20 \mu \mathrm{g} / \mathrm{l}$ \\
\hline $\mathrm{Fe}$ & $0.998-1.895$ & $0.984-1.283$ & $0.689-0.786$ & $0.513-0.588$ & & & $200 \mu \mathrm{g} / \mathrm{l}$ \\
\hline $\mathrm{Mn}$ & $0.624-1.748$ & $0.531-0.859$ & $0.414-0.511$ & $0.04-0.063$ & & & $50 \mu \mathrm{g} / \mathrm{l}$ \\
\hline $\mathrm{Al}$ & $0.897-1.991$ & $0.993-1.432$ & $0.933-1.621$ & $0.654-0.878$ & & & $200 \mathrm{mg} / \mathrm{l}$ \\
\hline
\end{tabular}

${ }^{1}$ Dutch List (Intervention Values for soils, 2000), ${ }^{2}$ European Communities (Drinking Water) Regulations 2007,

${ }^{3}$ EPA (Environmental Protection Agency), * non polluted sludge. 
than the recommended value for this element as the maximum of $20 \mu \mathrm{g} / \mathrm{l}$. Additionally, in the sludge samples, it can be seen that the samples are non-polluted, comparing the value of lower than $20 \mathrm{mg} / \mathrm{kg}$ which can be considered as nonpolluted sludge.

From the obtained results, it can be noticed that the pollution is not severe. In most of the cases, the elements presented did not exceed the maximum amount allowed, excluding $\mathrm{Ni}$ and $\mathrm{Pb}$ in the samples of water. However, these comparative values were made with drinking water, and the samples taken for analysis were from the river Lepenci which is not used directly as drinking water.

\section{CONCLUSION}

According to the results obtained from the measurement of $\mathrm{Pb}, \mathrm{Zn}, \mathrm{Cu}, \mathrm{Ni}, \mathrm{Fe}, \mathrm{Mn}$ and $\mathrm{Al}$, it can be seen that the concentration of these elements are within the allowable limits. On the assumption of water sample, some of the elements were higher than drinking water standards. From different perspectives of the current study, the average of ecological risk potential is described as a region with low polluted zone with heavy metals due to the cement factory. In order to verify the results, and to keep the area under control due to the cement factory that can release a greater amount of pollution, it is advisable to keep the continuous monitoring and analysis of the region.

\section{REFERENCES}

1. Vardhan K.H., Kumar P.S., Panda R.C. 2019. A review on heavy metal pollution, toxicity and remedial measures: Current trends and future perspectives. Journal of Molecular Liquids. Journal of Molecular Liquids 290, 111197.

2. Liu Y., Su C., Zhang H., Li X., Pei J. 2014. Interaction of soil heavy metal pollution with industrialization and the landscape pattern in Taiyuan city, China, PloS one, 9(9), p.e105798.

3. Nagajyoti P.C., Lee K.D., Sreekanth T.V.M. 2010. Heavy metals, occurrence and toxicity for plants: a review. Environmental chemistry letters, 8(3), 199-216.

4. Lutts S., Lefèvre I. 2015. How can we take advantage of halophyte properties to cope with heavy metal toxicity in salt-affected areas, Annals of Botany, 115(3), 509-528.
5. Jusufi K., Stafilov T., Vasjari M., Korca B., Halili J. and Berisha A. 2017a. Measuring the presence of heavy metals and their bioavailability in potato crops around Kosovo's power plants, Fresenius Environmental Bulletin 26(2a), 1682-1686.

6. Raia P.K., Leeb S.S., Zhangc M., Tsangd Y.F., Kime K.-H. 2019. Heavy metals in food crops: Health risks, fate, mechanisms, and management. Environment International, 125, 365-385.

7. Jusufi K., Vasjari M., Korca B. 2017b. Evaluating the heavy metals in dust pollution in Cabbages in Kastriot, Kosovo. Journal of Chemical Technology and Metallurgy, 52(5), 956-961.

8. Korça B., Demaku S. 2020. Evaluating the presence of heavy metals in the vicinity of an industrial complex. Pol. J. Environ. Stud. 29(5), 3643-3649.

9. Demaku S., Bajraktari N. 2019. Physicochemical analysis of the water wells in the area of kosovo energetic corporation (Obiliq, Kosovo), 20(7), 155-160.

10. Jusufi K., Stafilov K., Vasjari M., Korca B., Berisha A. and Halili J. 2016. Determination of heavy metals by ICP-OES in the agricultural soils surrounding Kosovo's power plants. Parlar Scientific Publications (PSP) Fresenius Environmental Bulletin, 25(5), 1312-1320.

11. Wekpel V.O., Chukwu-Okeah G.O. and Kinikanwo G. 2019. Road Construction and Trace Heavy Metals in Roadside Soils along a Major Traffic Corridor in an Expanding Metropolis. Asian Research Journal of Arts \& Social Sciences 8(3), 1-10. Article no.ARJASS.46216 ISSN: 2456-4761.

12. Boateng T.K., Opoku F., Akoto O. 2019. Heavy metal contamination assessment of groundwater quality: a case study of Oti landfill site, Kumasi, Applied Water Science 9:33 https://doi.org/10.1007/ s13201-019-0915-y

13. Isikli B., Demir T., Urer S.M., Berber A., Akar T., Kalyoncu C. 2003. Effects of chromium exposure from a cement factory, Environmental research, 91(2), 113-118.

14. Isikli B., Demir T.A., Akar T., Berber A., Ürer S.M., Kalyoncu C., Canbek, M. 2006. Cadmium exposure from the cement dust emissions: a field study in a rural residence, Chemosphere, 63(9), 1546-1552.

15. Canbay H.S., Doğantürk M. 2016. Metals determination by Microwave digestion ICP-OES of some dietary supplements and diet products in Turkey. Open Access - Eurasian Journal of Analytical Chemistry, 45-50.

16. Kadhum S.A, Ishak M.Y, Zulkifli S.Z. 2015. Evaluation and assessment of baseline metal contamination in surface sediments from the Bernam River, Malaysia.

17. USEPA, Method (3050B). 1996. Acid Digestion of 
Sediments, Sludges, and Soils. Revision 2, USEPA, Washington, DC, USA.

18. Skoczylas K., Rucińska T.. 2020. Influence of grain shape of waste glass aggregate on the properties of cement mortar. Journal of Ecological Engineering, 21(1), 148-159 https://doi. org/10.12911/22998993/112975.

19. Tahri M., Benyaich F., Bounakhla M., Bilal E., Gruffat J.J., Moutte J., Garcia D. 2005. Multivariate analysis of heavy metal contents in soils, sediments and water in the region of Meknes (central Morocco). Environ. Monit., Assess, 102, 405.

20. Vongdala N., Tran H.D., Xuan T., Teschke R., Khanh T. 2018. Heavy metal accumulation in water, soil, and plants of municipal solid waste landfill in Vientiane. Int. J. Environ. Res. Public Health, 16, 22.

21. Jia, Z., Li, S., Wang, L. 2018.Assessment of soil heavy metals for eco-environment and human health in a rapidly urbanization area of the upper Yangtze Basin. Sci Rep 8, 3256. https://doi.org/10.1038/ s41598-018-21569-6.

22. Wang Y.C., Ao L., Lei B., Zhang S. 2015. Assessment of heavy metal contamination from sediment and soil in the riparian zone China's Three Gorges Reservoir. Polish Journal of Environmental Studies 24(5), 2253.

23. Dutch Target and Intervention Values, 2000 (the New Dutch List). 